\title{
Editor's introduction to volume 5
}

The first volume of Popular Music had a theme which was, at least in part, historical: how and when does 'folk music' become 'popular music'? What happens in the music, in the culture, or in the discourses of practitioners, critics and ideologists, to cause that movement? We end our first Five Year Plan by returning to a historical theme, this time more directly.

The rise of popular music studies in recent years, centred mostly on contemporary forms, has left the historical dimension relatively untheorised; or at least it has contributed to a separation between that central preoccupation and other perspectives more interested in understanding the past and in the phenomenon of change: folklore; musical, social and economic history; ethnomusicology (through its concern with acculturation, for instance). Yet ironically the notion of change is everywhere in the discourses of popular music; to traditional preoccupations, designated by such concepts as influence, development, originality and period, are added the symptoms of a collective consciousness formed within the dictates of contemporary capitalist cultural production: turnover, novelty, revival, cross-over. It could be argued that an important characteristic of the whole story of urban popular music, from its beginnings and increasingly today, is its breathlessness. At the same time, however, there is a strong case for an opposite perspective. There is now a pervasive feeling of global paralysis, in culture as in politics: how much change does all this change really signify? This can also be argued from an anthropological or conservative historical standpoint - man's basic needs are constant; the common man and his culture are always there, never really changing, etc. But a more powerful case is mounted by critical cultural theory, from the Frankfurt School's descriptions of culture industry standardisation to more recent analyses of what Fredric Jameson calls the culture of the simulacrum, in which everything is an image of something else, nothing an original. Within the 'post-modernist' rubbish heap, its content extending across the globe and through the ages, history itself comes into crisis, unsure of what might constitute a historical period, or subject, narrative or determinant, or even, at a deeper level, whether the concept of the past - or the future - has meaning at all. 
It would be absurd to pretend that the articles collected here can solve problems of this order. At best, their complexity is confirmed: different historical moments throw up cases that are the same - or different; the same moment is differentially interpreted; borrowing is also theft, or synthesis; cultural imperialism triumphs - but provokes novel responses or determined continuities as well; and so on. Perhaps too the suggestion emerges that one way to tackle the problem - even if ultimately this makes unwarrantable assumptions about its premises is to stress the importance of differentiation: differentiation not so much of musical product and practice as of analytical level (performer, style, culture, system of production, medium, instrument, genre, ideology, etc.) and of factor (syntactic convention, institutional structure, technological innovation, audience interpretation, etc.).

The first article, by Richard Middleton, offers a framework within which the historical location of particular popular music moments in the general pattern of music history could be grasped. The thinking here is on a rather large historical scale, but also focuses on how the factors operating at that level constellate, to 'articulate' specific cases. The next three pieces (by Mark Tucker, John Cowley and Alan Durant) look at single, defined situations, moving from the level of the individual musician (Count Basie), at a particular moment (the 1930s), working within a developing but relatively stable tradition; through a study of two representative individuals involved in a more fluid situation with international and cross-cultural aspects, which nevertheless manifests interesting evidence of continuity (West Indian musicians in the USA and Britain between 1918 and 1951); to a discussion of a formed music culture as a whole (rock music), one that undoubtedly emerged from acculturative and synthesising processes but is now subject to competing assessments of the extent to which it represents change.

While the complexity of factors and interpretations is certainly already clear, the next two articles remind us that, even so, in certain circumstances, the course of popular music development can be affected very obviously and directly, notably when political authorities have an interest in making use of, or controlling, that development. Terry Bright describes how musical change has been halted by the authorities in the Soviet Union; while, in an interesting contrast, Peter Wicke discusses the way that, in a very different social and political situation, the rulers of Fascist Germany drew on continuities in the popular music of the time, harnessing them to new purposes. It is equally obvious, however, that popular music can be harnessed to the needs of political struggle as well as those of control, and that this can have direct effects on the music's development too. The point is well 
illustrated, somewhat later in this volume, in Jan Fairley's introduction to her bibliography of Latin American popular music, which focuses on the Chilean nueva canción.

The spread of American styles is a background to both Bright's and Wicke's articles (and American cultural imperialism is an essential element in Fairley's discussion). It comes more to the fore in Charles Hamm's piece on the reception of rock ' $n$ ' roll in South Africa, which, moreover, is also directly concerned with political factors. But Hamm is interested too in the different uses made of this music by various social groups, and with the way its reception by black South Africans fits into a history of acculturation of American forms. Cross-cultural change involving American sources is also the theme of Jean-Claude Klein's article, though here the subject - Fench music hall and revue between the wars - is treated not only in the context of social and political conditions but also in terms of the conditions of cultural production within which particular syntheses could take place.

In the last two articles, the themes of cultural imperialism and acculturation continue. First, George $\mathrm{H}$. Lewis describes the impact on Hawaiian music of the culture of its giant neighbour, and its response; but he concentrates on the interesting fact that the two styles, cosmopolitan and nationalist, can co-exist, even within the practice of the same musicians. Then Erik Cohen and Amnon Shiloah discuss the multiple responses of Oriental Jewish immigrants to Israel, confronted by the superior power and status of styles derived from European traditions.

Cohen and Shiloah end with a salutory stress on the difficulty of making one-to-one correspondences between musical, social and ideological changes. But here, and throughout the articles collected in this volume, there seems to be reflected not only a lack of fit, a bewildering plurality of musics and meanings, but, at the same time and at a different level, something of a general trend towards a certain convergence; after all, to - say-a British listener, probably all of the musics discussed here would be 'understandable', and that would not have been true of an analogous selection of 'folk' and 'popular' musics, say, a century ago. Amid the hype of music industry 'progress' on the one hand, and the pessimistic closure effected by so much critical cultural theory on the other, I turn for inspiration to Walter Benjamin's tremendously sober re-interpretation of both Marxist teleology and Jewish utopianism, his picture of the 'angel of history', which seems peculiarly relevant to the post-modern stasis, if such it is:

His face is turned towards the past. Where we perceive a chain of events, he sees one single catastrophe which keeps piling wreckage upon wreckage and hurls it in front of his feet. The angel would like to stay, awaken the dead, and 
make whole what has been smashed. But a storm is blowing from Paradise; it has got caught in his wings with such violence that the angel can no longer close them. This storm irresistably propels him into the future to which his back is turned, while the pile of debris before him grows skyward. This storm is what we call progress. (Benjamin 1973, pp. 259-60)

\section{References}

Benjamin, W. 1973. 'Theses on the philosophy of history', in Illuminations, ed. H. Arendt, trans. H. Zohn (London), pp. 255-66 